\title{
Alex Long* \\ Seneca on Human Rights in De Beneficiis 3
}

https://doi.org/10.1515/apeiron-2019-0019

Abstract: The paper discusses Seneca's phrase 'human rights' (ius humanum) in On Benefits 3 and relates the passage to recent debates about human rights in Stoicism and ancient philosophy. I argue that the Latin phrase refers either to rights or to a law conferring rights. The difference between the passage and a common expectation for human rights lies in the kind of relation between right and duty. In Seneca's passage the right does not in itself have a correlative duty on the part of other people, and yet it does, if exercised through benefactions, create a duty in others. By contrast, the relation between right and duty is usually expected to be unconditional.

Keywords: human rights, Seneca, society, Stoicism

This paper is about a passage in De beneficiis where Seneca attributes 'human rights' (ius humanum) to slaves. The passage, T1 below, receives a brief discussion in a recent discussion of Stoicism and human rights, but it repays fuller treatment. ${ }^{1}$ Exploring in more detail how it relates to philosophical discussions of human rights today throws light on our own expectations of what is involved in attributing a right, and of what should motivate the attribution; and for the task of relating the passage to our expectations the broader context of the passage - Seneca's social theory and writing on gratitude - is not a distraction but indispensable. In what follows I first discuss the meaning and translation of the Latin wording; I then compare the passage with three arguments against attributing to Stoics, or to ancient philosophers more generally, the concept of human rights. On my account, the most important difference between the Senecan passage and our own attributions of human rights lies in the kind of

1 Bett (2012, 154-55) says that ius humanum in the passage 'sounds remarkably like "human rights”'. In his survey of philosophical discussions of slavery Garnsey cites the passage (1996, 67 n.6) but selects others for quotation and discussion. What follows focuses on the meaning of ius humanum; for fuller accounts of slavery in Seneca see, in addition to Garnsey (1996), Griffin (1992), chap. 8, Bradley (2008). It is not part of my project to consider whether Seneca is, in Bradley's words (2008, 340), 'enlightened and liberal'.

*Corresponding author: Alex Long, School of Classics, University of St Andrews, St Andrews, UK, E-mail: agl10@st-andrews.ac.uk 
connection between the right and the duties of others on which the right has a bearing.

In De beneficiis Book 3 Seneca argues that a slave can bestow a benefit upon his master. Denying that this ever happens shows, he says, ignorance of 'human rights'.

T1 Praeterea servum qui negat dare aliquando domino beneficium, ignarus est iuris humani; refert enim, cuius animi sit, qui praestat, non cuius status. Nulli praeclusa virtus est; omnibus patet, omnes admittit, omnes invitat, et ingenuos et libertinos et servos et reges et exules; non eligit domum nec censum, nudo homine contenta est.

Moreoever, someone who denies that a slave ever gives his master a benefit is ignorant of human rights: what matters is the mind of the person who bestows something, not his political status. ${ }^{2}$ Nobody is barred from virtue: it is open to everyone, admits everyone, summons everyone - freeborn, former slaves, current slaves, kings and exiles. Virtue does not choose ancestry or property; the bare human being is enough for it. (3.18.2) ${ }^{3}$

Seneca and his opponent - the person said to be 'ignorant' - do not disagree about what slaves should do for their masters. ${ }^{4}$ Their disagreement concerns what a slave is capable of doing and whether we should speak of a slave benefiting his master: does the slave's status bar him from conferring benefits? No, Seneca says, merely by being a human being the slave is capable of bestowing a benefit and, more generally, of virtue and virtuous action. So if a master is to understand his own slaves' moral potential, including their potential in relation to the master himself, he should look not to the slaves' status but to their humanity. ${ }^{5}$ As Seneca says later, 'does a master receive a benefit from his slave? No, one human being receives a benefit from another. To conclude, he [the slave] has done what was in his power (in illius potestate)' (22.3-4). Seneca then adds immediately that the master has the power to decline the benefit, $a$ point to which we will return.

The Latin phrase ius humanum could mean, among other things, 'human law', 'correct behaviour between humans' or 'human duties and rights'. We can

2 For the mind or intention as all-important see also 1.1.8, 1.6.1, 4.21.3, 6.9.3; Griffin (2013, 27). 3 All translations are mine unless indicated otherwise. The Latin text is that of Basore in the Loeb Classical Library (1935). Unlike Basore recent English translators (Cooper and Procopé 1995; Griffin and Inwood 2011) accept the transposition of 18.2 and 18.3, but this does not affect my discussion or translation of $\mathrm{T} 1$.

4 Hecaton of Rhodes is said to have raised the question of whether a slave can confer benefits (3.18.1), but Seneca does not tell us his answer and so we should not call his opponent 'Hecaton'. For the relationship between Hecaton and Seneca's De beneficiis see Inwood (2005, 70-1); Griffin (2013, 20-1 and 24).

5 For the slave/human contrast see also De clementia 1.18.2, Letter 47.1. 
use the opponent's position in T1 to clarify its meaning and see whether the translation provided above, 'human rights', is better than these alternatives. The opponent is ignorant of this ius. But the opponent is not necessarily ignorant of which kinds of action constitute right or appropriate behaviour: Seneca's opponent may know full well what the slave should do in his circumstances. ius points to what the slave can do or is entitled to do, or (to quote 3.22 again) what is 'in his power', not what he should do or what it is right to do. The Latin word can do so in one of two ways: either (1) ius simply means 'rights' or 'entitlements' or (2) it means the law by which the slave has those rights or entitlements. On (2), we should translate ius humanum as 'human law' or something similar, but the passage would still criticize the opponent for failing to recognize the slave's right to benefit and to be virtuous: Seneca would be saying that the opponent's ignorance of 'human law' blinds him to the fact that this law, unlike Roman law, does not look to social status when endowing people with rights. So although the Latin word ius can certainly encompass duties as well as rights, in T1 Seneca means by ius either rights and entitlements, or law as a source of them. English translators have recently chosen the first, 'rights', but the other translation, law, also seems to me defensible. ${ }^{6}$ If we opt for interpretation (1), 'rights' is better than 'right', even though Seneca uses ius in the singular: the Latin word does not need to be in the plural to represent a system or set of rights, laws or duties, and Seneca soon goes on to argue that the slave can be just and brave as well as a benefactor (3.18.4). The opponent is shown that the slave has multiple moral possibilities.

The adjective humanum then indicates that the possibilities for the slave derive simply from his being a human being and are shared with all other human beings. ${ }^{7}$ On interpretation (1), the meaning is that the slave has these rights as a human being. On interpretation (2), it is that the law - presumably the natural, providential law - concerning the moral range of human beings entitles slaves to supreme moral achievements; the opponent is ignorant that all

\footnotetext{
6 Cooper and Procopé (1995) ('his rights as a man'); Griffin and Inwood (2011) ('the rights he has as a human being'). Préchac (1926-1927) has 'les droits de l'homme', and Basore (1935) has 'the rights of man'. Compare the translation in Horsfall (2000) of ius maternum in Virgil Aeneid 7.402 ('a mother's rights'). The speaker has in mind not a mother's obligations (that is, her duties to her daughter), but her right as a mother to the other mothers' sympathy and solidarity. When commenting on the same line of Virgil, Fordyce (1977) notes that 'ius is the code or system of rights and duties which is recognized in some form of human relationship', but nevertheless suggests 'a mother's rights' (rather than e. g. 'a mother's duties and rights') as the translation. My thanks to Harry Hine for discussion of the translation.

7 Contrast e. g. the right or ius of a mother (Virgil Aeneid 7.402, discussed in the previous note) and the rights (iura) of parents in inheritance (Juvenal 9.87).
} 
human beings, slaves included, have these possibilities in common, and that status in Roman law, as slave, exile and so on, or in some other local law (as king, for example) makes no difference.

Elsewhere in De beneficiis Seneca uses the same phrase, ius humanum, to refer not to rights belonging to a person, but to the norms governing interaction between all human beings. ${ }^{8}$ In Book 7 Seneca asks whether a benefit should always be repaid, regardless of the character of the benefactor. He imagines a case where the benefactor is a horrifically cruel tyrant: in such a case, he says, the tyrant has flouted the norms of interpersonal behaviour so comprehensively that the individual bond, between the tyrant and the beneficiary, is also broken.

T2 Quidquid erat, quo mihi cohaereret, intercisa iuris humani societas abscidit.

His [the tyrant's] breaking the fellowship of right and wrong between humans has severed whatever it was that gave him a bond with me. $(7.19 .8)^{9}$

The tyrant's offences may have been against other people, such as his own subjects and their children (19.8-9), not the beneficiary himself. Even so, Seneca says, the offence against humanity makes null and void the tyrant's claim to have his benefit repaid by an individual whom he has not harmed. In one of his letters Seneca considers the opposite, benign process: correctly observing the norms and laws governing all interpersonal behaviour (commune ius generis humani) makes a positive contribution to the more intimate bond of friendship between individuals (48.3).

In T1, however, ius points to what the slave is capable of doing, either as the law that confers rights or as the rights themselves. ${ }^{10}$ The force of humanum is also different in the two passages. In T1, unlike in T2, it does not restrict the point to proper treatment of other people, even though Seneca is arguing for a point about interpersonal benefaction. The meaning is that by being human the slave has been made capable of acting virtuously. In Stoicism such acts need not be between people: a slave can exercise his right to act virtuously by meeting

8 See also 7.2.4 (divini iuris atque humani peritus). This expert knows not the gods' 'rights' but what one should do in relation to the divine; ius humanum should be given a similar interpretation. So too in Cicero De partitione oratoria 129-30 (divinum et humanum ius). Compare commune ius animantium (Seneca De clementia 1.18), or ius humanum in Oedipus 1026. Inwood (2005, 230-31) brings together some of the key Senecan passages.

9 intercisa iuris humani societas is translated 'the breaking of our bond of shared humanity' in Griffin and Inwood (2011). Cooper and Procopé (1995) do not include Books 5-7.

10 For ius in a subjective sense in Roman law see Donahue (2001), Donahue (2010, 71-2), and Tierney (1997, 15-19). 
illness or pain with courage, or by revering the gods with appropriate piety. ${ }^{11}$ In T2, by contrast, ius humanum consists exclusively of how to treat, and engage with, other human beings correctly; those norms, when observed, bind people together in fellowship, and when they are hideously broken by a tyrant the bonds between him and others are annulled.

We can now move on from the Latin wording and compare T1 with three arguments put forward against attributing to Stoics, or other Greek and Roman philosophers, the concept of human rights. ${ }^{12}$ One argument is about the unimportance, in Stoicism, of such items as bodily health, life, poverty and slavery (in the familiar social sense, rather than self-enslavement as a moral failing). ${ }^{13}$ According to this argument, a theory of rights must attribute significant positive or negative value to these items. Unless we regard health, life (and so on) as good and contributing to human welfare, and poverty, slavery (etc) as bad, we will not be motivated sufficiently to promote or preserve the former in other people, and to rescue and safeguard people from the latter. Stoicism, the objection then runs, fails to treat life (etc) as a genuine good, and poverty (etc) as an evil, and so it fails to recognize the importance of items for which people have rights. ${ }^{14}$

At most this shows that Stoics do not have our theory of rights. ${ }^{15}$ But when judging whether they have $a$ theory of rights it is not certain that we should use our own axiology as the measure. Arguably what matters is whether people are

11 Courage is mentioned in 3.18.4. For courage and piety as Stoic virtues see, for example, Plutarch On Stoic self-contradictions 1034d-e, SVF 3.264 and 604. Unlike courage and justice, courage and piety are not coordinate, as piety is subordinate to justice.

12 The arguments are taken from Burnyeat (2012) and Bett (2012). Burnyeat writes about the ancient Greeks. Bett (2012) focuses on Stoicism, Roman as well as Greek, and concludes that Stoics had the notion of human rights only to a limited extent. Cooper and Procopé briefly compare and contrast T1 with a 'political doctrine of universal human rights' (1995, 190, n.27). 13 For moral self-enslavement to desires and fears see De beneficiis 3.28.4, Letter 47.17, Frede (2011, 67).

14 Bett (2012, 161-68).

15 Bett speaks of a 'normal understanding' and a 'recognizable understanding' of human rights (2012, 150, 164). Bett offers a further consideration against attributing a 'robust' $(2012,149)$ notion of human rights to Stoics: the gulf between the sage and all other people (2012, 158-61). But strongly divergent moral evaluations of a sage and a non-sage, and the strongly contrasting descriptions of them that we find in Stoic sources, do not imply that the sage and the non-sage should be treated differently when in need of material or other forms of assistance. If sages are entitled to different treatment, it is because of what they can do for others, not their own wisdom or virtue (Cicero De officiis 3.29-31, 89; compare the discussion of two sages in 3.90, although there both the community's interests and the sage's own interests are said to be relevant). 
thought to have a right for what is, according to Stoicism itself, good or most valuable. That measure delivers a very different verdict: Seneca is saying that the slave has a right for everything that is genuinely good (virtue and what follows from virtue, especially virtuous action). Moreover, in speaking of 'our' theory of rights, or the 'normal' theory, there is a risk of overstating the agreement in the twentieth and twenty-first centuries about the range of items for which people have rights. I have in mind not only debates about whether people have a right to possess items, or engage in practices, that become possible or noticed only after and as a result of social or technological change, such as the right to online privacy. There are also debates about long-standing ways in which people differ, such as poverty, liberty and social exclusion. ${ }^{16}$ Two people may disagree about the list of items for which people have rights, and yet it would be inappropriate for one of them to use his or her own view about what is valuable or a contributor to welfare to deny that the other person has a theory of rights at all. As long as the question is whether Stoicism has $a$ theory of rights, it is not disqualified if its evaluation of health, poverty, slavery and so on bars it from treating people as having rights concerning those particular items.

Establishing whether or not Stoic evaluation really does have this implication would require detailed discussion of their theory of 'promoted' and 'demoted' indifferents, such as health and poverty. I will not pursue that in detail, as it is not relevant to T1, which is about the right to benefit, not the right to freedom, life, health and so on. But if a theory of rights is to be more than a list of aspirations or desiderata, it does seem intuitive to use the importance of an item to our welfare as a consideration when deciding whether or not people have a right to it. ${ }^{17}$ Stoics may be able to show that their theory gives us good reason to promote health (etc) in other people, and so that in a Stoic community parents would take care of sick children, doctors would carry out their job diligently, and so on. But this does not show that health would be protected and promoted as something to which people have a right. The same point applies to other items, such as life and poverty, to which or against which we might say that people have rights.

The second argument is about the relationship between rights and duties, such as my right not to be lied to and your duty not to lie to me. Which of them justifies the other? According to Burnyeat, the concept of rights requires rights to

16 See e. g. Dworkin's challenge to the view that people have the right to liberty (1978, chap. 12, 'what rights do we have?'), or Brownlee's argument for an unacknowledged right against social deprivation (2013).

17 In Brownlee (2013) importance is used as one of several 'tests' for human rights. See also Tasioulas (2007, 77 and 92). 
be prior to duties in the sense that the duty is justified with reference to the right, not vice versa: it is because I have a right not to be lied to that you should not lie to me. ${ }^{18}$ If the justification goes in the other direction (my right derives from your duty), the right is not fundamental. 'I should not want to speak of a concept of human rights until the beneficiaries come first in the order of justification. ${ }^{19}$

For the sake of argument let us concede to Burnyeat that this order of justification really is, as he holds, a necessary condition for a theory or concept of rights. In $\mathrm{T} 1$ itself there is no relation of justification between a duty and a right. (We will see later, however, that the broader context of $\mathrm{T} 1$ does imply a claim about duties.) The slave possesses the right to be a benefactor, not a beneficiary, and the slave possesses this right independently of the duties of others. It derives simply from his being human. If Burnyeat's point is only the negative one that a right must not be justified with reference to duties, it has no force against attributing to Seneca a concept of rights in T1 - for there are no duties in the passage from which the right follows. But if Burnyeat is also stipulating that a right must have as a direct corollary duties on the part of others, his point would indeed bar the attribution. Seneca does not argue that the slave's right to benefit his master calls, in itself, for other people, such as the master himself, to treat the slave in certain ways - or not to treat him in certain ways. The obligation is theoretical or conceptual, not practical: we must think of the slave as capable of benefiting others. Seneca and his fellow Stoics, such as Hecaton, must recognize this right in their moral theory, not in action. ${ }^{20}$

This starts to show how T1 differs from common expectations for theories of human rights, and it brings me to the third and most powerful argument. People's right to something must have as its counterpart a duty in others to provide it to them, or not to prevent them from having it:

The idea of a right to these things is meaningless, because they cannot be conferred on a person, or taken away from a person, by others; if one is wise, one has them, and if one is not, one does not, and that is the end of the story. ${ }^{21}$

18 Burnyeat (2012, 285-87). Burnyeat cites the account in Dworkin (1978, 171), which is the source of the example. Dworkin for his part was arguing merely that treating rights, not duties, as fundamental makes a difference to the character of a theory; he was not arguing that making rights fundamental is a necessary condition for having the concept of rights at all (1978, 171-77). Tasioulas $(2007,99)$ helpfully distinguishes between ways in which rights or duties can be prior.

19 Burnyeat (2012, 286).

20 For Hecaton see $n .4$ above.

21 Bett (2012, 164). See also Bett (2012, 162-63), where he suggests that if other people cannot secure for you the items for which you have a right, the 'notion of rights has no application'. 
To put the point more generally: someone does not have a genuine right unless other people have correlative duties, and the existence of a right implies the existence of duties for others. Within the modern literature this is a venerable position: according to Hohfeld's (still foundational) study, if person X has a right 'in the strictest sense' or the 'proper meaning', that right has, as its correlative, Y's duty to act or refrain from acting. ${ }^{22}$ Hohfeld distinguishes these (genuine) rights from other legal relations that are often called 'rights'. But it has been argued that a wider range of relations counts as rights - even by studies that otherwise follow Hohfeld closely. For example, arguably there are cases where $\mathrm{X}$ has a right to perform an action by virtue of not having a duty to refrain from it: people without a driving licence have a duty not to drive cars, but someone who gains a driving licence is exempted from that duty and now holds the (legal) right to drive a car. ${ }^{23}$ It is now the right-holder's own duties that are relevant, not those of other people.

In philosophical discussions of rights it is not agreed, then, that a right can be attributed to a person only if other people have a duty to act or refrain from acting. But in order to avoid resting my argument on one position in the modern literature, I will stack the cards against the attribution of 'human rights' theory to Stoics by assuming that the possession of a right implies that other people have duties. To develop this assumption further: let us suppose that the point of the discourse of 'rights' is to identify areas where people are vulnerable, and others (individuals, institutions or governments) mighty, or at least able to harm or benefit. Attributing rights to people, on this view, responds to human vulnerability and stipulates what should be done for them and should not be done to them. Often it is motivated by what has or has not been done in the past: negligent, exploitative, cruel or even worse treatment that has caused people

Compare the following: 'rights are seen as one side of a normative relationship between rightholders and obligation-bearers. We normally regard supposed claims or entitlements that nobody is obliged to respect or honour as null and void, indeed undefined' (O'Neill 2005, 430). 22 Hohfeld (1919, 36 and 38).

23 See Wenar (2005), especially 226 (the source of the example). Hohfeld argued that these relations should be called 'privileges' and thereby sought to distinguish them from rights in the proper sense. By contrast, Wenar presents privileges as one kind of right, and claims (where other people have duties), which alone count as rights for Hohfeld, as another kind ('claimrights'). 'Some rights are privileges, and some rights are claims' (Wenar 2005, 229). On the other hand, Wenar requires a right to perform one or more of six 'functions', such as protection or authorization (2005, 246). See also Wenar's entry on rights in the online Stanford Encyclopedia of Philosophy, https://plato.stanford.edu/entries/rights/. Here too Wenar argues that not all rights are 'claims' and imply that other people have duties. 
harm. ${ }^{24}$ Seneca approaches the topic of rights in a completely different spirit. He wishes to show that, in respect of their ability to act virtuously, slaves are invulnerable; people necessarily have the ability to act virtuously, no matter what becomes of their social status. ${ }^{25}$ Slaves cannot be harmed by others by being stripped of this ability. And slaves cannot be benefited by others either, in respect of the slaves' own virtuous action: nobody can carry out a slave's virtuous action, or do it for the slave, except the slave himself.

This is not merely to say that the slave's right is inalienable, if by that we mean that the right itself cannot be forfeited by bad conduct or by renouncing it. Someone could have an inalienable right to free speech, for example, and yet be denied free speech by the actions of others: the right remains, but the person is compelled to keep silent. Seneca means not only that the right itself is inalienable, but that the slave cannot be prevented by other people, his social circumstances, and so on from having that for which he has the right, namely virtue and virtuous action.

But before we conclude that the rights in $\mathrm{T} 1$ have no connection at all with the duties of other people, we need to consider the broader social theory to which the passage is contributing. De beneficiis attaches enormous importance to receiving benefits correctly and, in particular, to gratitude $(2.22-35,3.1-5$, 4.40, 6.25-43, 7.14-16.4). As soon as someone accepts a benefit he or she should think about how to repay it (2.25.3). Seneca's assertion in T1 that slaves can confer benefits brings the slave-master relationship into this framework. It has, in this context, the practical implication that a master can have the obligation to his slave of repaying a benefit. ${ }^{26}$

T3 An aecum videtur tibi, quibus, si minus debito faciant, irascimur, non haberi gratiam, si plus debito solitoque fecerint?

We get angry with slaves if they do less than they should - do you think it right not to be grateful to them if they have done more than their usual duties? (3.22.2)

Characteristically Seneca provides examples to support his argument that slaves can provide benefits, and two of those examples end with the slaves manumitted

24 'Disregard and contempt for human rights have resulted in barbarous acts which have outraged the conscience of mankind' (Universal Declaration of Human Rights, 1948, https://www.un.org/en/ universal-declaration-human-rights/index.html).

25 Elsewhere he says that we are born 'with equal rights' (aequo iure), but one person has been given (presumably as a slave) to another (Consolation to Marcia 20.2). The contrast suggests that people no longer possess, or no longer can exercise, these rights; and so the rights must be different from those of T1.

26 Griffin and Inwood show this succinctly in their introduction (2011, 7). 
by grateful masters $(3.23 .3,3.27 .4)$. Of course, a slave may fail to take an opportunity to benefit his master, and a master may decline a slave's benefit (3.22.4), either by simply refusing it or by pre-emptively manumitting the slave and so receiving the benefit without its coming from a slave. ${ }^{27}$ But manumission may be impractical and refusing the slave's benefit may have a prohibitively high cost, such as when slaves rescue their masters from imminent death (3.23.2-4).

The connection between the slave's right and the master's duty to repay is not direct but conditional on both the slave's exercising in his actions the right to benefit and the master's choosing to receive the benefit, at least in cases where refusal is a real option for the master. So the difference between $\mathrm{T} 1$ and the expectations for human rights outlined above is not that the slave's right has no bearing at all on the duties of others. It is rather that (a) the connection between right and duty is indirect and conditional, and (b) the duty is not to provide the item(s) for which the slave has a right, namely virtuous action. That is, (a) the slave's right to benefit creates a duty for his master - but only if exercised, and if the master does not refuse the benefit. And (b) the slave's 'rights' are to act virtuously and benefit others, and nobody can bestow virtuous action upon the slave: it is up to the slave to attain virtue himself.

Showing how Seneca conceives of human rights in T1 thus demands attention to the account of human interaction, and interpersonal obligations, defended elsewhere in De beneficiis. We are not in a position to say to what extent his concept of a human right resembles ours until we look to this social theory. In this regard we can take as our model Frede's account (2011) of free will in Stoic and other ancient philosophy, which keeps in sight the moral and theological assumptions underpinning Stoic accounts of free will. In fact, Frede's book contains a powerful description of how the world's providential design confers upon slaves their right to be virtuous:

There is in addition the assumption that this world down to the smallest detail is governed by a good and provident God, and that this God, in creating the world, has made sure that neither human nature nor our individual nature and constitution nor the circumstances into which we are born, nor the conjunction of these three factors, would prevent us from developing in such a way as to be able to make the right choices and decisions in our life. ${ }^{28}$

Nobody and nothing except the slave himself can deny him the virtuous actions for which he has a god-given right. Stoics would find extraordinary the idea that

27 The option of refusing a benefit is mentioned elsewhere and does not concern only masters and slaves. See Seneca's discussion of the people from whom we should accept benefits (2.18.221.6).

28 Frede $(2011,85)$. 
God or the gods could give the slave a right to something, and someone else then prevent the slave from having that very item.

This assumes that conferring a benefit requires nothing more than virtue and virtuous action. But there is a difficulty for Seneca, and it arises from the fact that other people can deny slaves the gratitude and repayment that their virtuous actions deserve. Some masters would be dismayed, not pleased, to find themselves with an obligation to a slave. Seneca does what he can to 'crush the arrogance' (3.29.1) of such masters and to provide examples where a slave's action is gratefully rewarded, such as the following: 'she freed them both immediately and did not resent the fact that she owed her life to those over whom she previously had the power of life and death' (3.23.3). All the same, it is undeniable that some think themselves, in Seneca's words, too good to receive benefits from slaves (3.28.4). And near the start of the work Seneca defines a benefit as an action that causes its recipient to feel joy.

T4 Quid est ergo beneficium? Benevola actio tribuens gaudium capiensque tribuendo in id, quod facit, prona et sponte sua parata.

What then is a benefit? A well-intentioned action conferring joy and, by conferring joy, receiving it, disposed and of its own accord ready to do what it does. (1.6.1)

It is hard to see how a slave's right to give a benefit, as defended in T1, can be squared with the definition in T4. ${ }^{29}$ T4 and other passages suggest that the mind of the recipient matters as well as that of the benefactor: a benefit is a transaction between two minds (2.34.1), and in conferring a benefit one seeks to give the recipient pleasure and cause him to feel gratitude $(2.31 .2-3,2.33 .1){ }^{30} \mathrm{~A}$ master's grudging attitude, or conception of himself as the slave's superior, can prevent a slave from causing the master 'joy', even through virtuous actions. So it is no accident that in T1, where Seneca argues that slaves can confer benefits, he turns to the slave's own virtue, not his causing joy in others, and then presents giving benefits as part of virtue (3.18.4). It is certainly within the slave's power to act virtuously by perfecting his reason and acting appropriately,

29 The same difficulty arises about the gods' benefits to all human beings, even the ungrateful and impious $(1.1 .9,2.29 .1-6,4.4 .3,6.23 .6-8,7.31 .2-4)$. There too it seems possible to provide a benefit without causing joy in the recipient, despite the definition in T4.

30 When arguing against the possibility of benefiting oneself Seneca assumes that, in interpersonal benefits, ingratitude causes the benefit to 'perish' (5.8.6). The fact that it does not perish when people supposedly benefit themselves without feeling gratitude is used to throw into doubt the whole idea of benefiting oneself. Contrast 5.20.2, where Seneca dismisses the emotion of the recipient: what matters is whether he ought to feel joy, not whether he actually feels it. 
which will involve careful choice of when, and to whom, he confers benefits. But no slave, however virtuous, can ensure on his own that his actions prompt the appropriate affective response in his master. Whether or not the slave has the ability attributed to him in T1 depends on whether providing a benefit successfully requires merely the right action and intention on the part of the benefactor or, in addition, joy in the beneficiary, as in the definition provided by T4. On that further question Seneca's text is ultimately undecided. ${ }^{31}$

\section{References}

Basore, J. W. 1935. Seneca: Moral Essays, vol. 3. Cambridge, Mass: Harvard University Press.

Bett, R. 2012. “Did the Stoics Invent Human Rights?” In Virtue and Happiness: Essays in Honour of Julia Annas, Supplementary Volume of Oxford Studies in Ancient Philosophy, edited by R. Kamtekar, 149-69. Oxford: Oxford University Press.

Bradley, K. R. 2008. "Seneca and Slavery." In Oxford Readings in Classical Studies: Seneca, edited by J. G. Fitch, 335-47. Oxford: Oxford University Press.

Brownlee, K. 2013. “A Human Right against Social Deprivation.” Philosophical Quarterly 63 (251): 199-222.

Burnyeat, M. F. 2012. “Did the Ancient Greeks Have the Concept of Human Rights?” In his Explorations in Ancient and Modern Philosophy, vol. 2. Cambridge: Cambridge University Press.

Cooper, J. M., and J. F. Procopé. 1995. Seneca: Moral and Political Essays. Cambridge: Cambridge University Press.

Donahue, C. Jr. 2001. "Ius in the Subjective Sense in Roman Law. Reflections on Villey and Tierney." In A Ennio Cortese, edited by D. Maffei, I. Birocchi, M. Caravale, E. Conte, and U. Petronio, 506-35. Rome: Il Cigno Edizioni.

Donahue, C., Jr 2010. “Ius in Roman Law." In Christianity and Human Rights: An Introduction, edited by J. Witte, Jr, and F. S. Alexander, 64-80. Cambridge: Cambridge University Press.

Dworkin, R. 1978. Taking Rights Seriously, New Impression with a Reply to Critics. London: Duckworth.

Fordyce, C. J. 1977. Virgil: Aeneid VII-VIII, edited by J. D. Christie. Oxford: Oxford University Press.

Frede, M. 2011. A Free Will: Origins of the Notion in Ancient Thought, edited by A. A. Long. Berkeley and Los Angeles: University of California Press.

Garnsey, P. 1996. Ideas of Slavery from Aristotle to Augustine. Cambridge: Cambridge University Press.

Griffin, M. 1992. Seneca: A Philosopher in Politics. Oxford: Clarendon Press.

Griffin, M. 2013. Seneca on Society: A Guide to De Beneficiis. Oxford: Oxford University Press.

31 Many thanks to Brad Inwood for raising in correspondence the difficulty discussed in this final paragraph, and to him and Harry Hine for their comments on a previous version of the paper. Thanks also to Samuel Mansell. 
Griffin, M., and B. Inwood. 2011. Seneca: On Benefits. Chicago and London: University of Chicago Press.

Hohfeld, W. N. 1919. Fundamental Legal Conceptions as Applied in Judicial Reasoning. New Haven: Yale University Press.

Horsfall, N. 2000. Virgil, Aeneid 7: A Commentary. Leiden, Boston and Köln: Brill.

Inwood, B. 2005. Reading Seneca: Stoic Philosophy at Rome. Oxford: Oxford University Press.

O’Neill, 0. 2005. “The Dark Side of Human Rights.” International Affairs 81: 427-39.

Préchac, F. 1926-1927. Sénèque: Des Bienfaits, vol. 2. Paris: Les Belles Lettres.

Tasioulas, J. 2007. "The Moral Reality of Human Rights." In Freedom from Poverty as a Human Right: Who Owes What to the Very Poor? edited by T. Pogge, 75-101. Oxford: Oxford University Press.

Tierney, B. 1997. The Idea of Natural Rights: Studies on Natural Rights, Natural Law, and Church Law 1150-1625. Grand Rapids, Michigan and Cambridge: Wm. B. Eerdmans Publishing Company.

Wenar, L. 2005. “The Nature of Rights.” Philosophy and Public Affairs 33 (3): 223-52. 